\title{
IziNambuzane: IsiZulu names for insects
}

\section{AUTHORS:}

Jessica J. Cockburn ${ }^{1 *}$

Ben Khumalo-Seegelken²

Martin H. Villet ${ }^{1}$

\section{AFFILIATIONS:}

'Department of Zoology and Entomology, Rhodes University, Grahamstown, South Africa

${ }^{2}$ Centre for South/NorthCooperation in Education and Research, Carl von Ossietzky University, Oldenburg, Germany

${ }^{*}$ Current address: School of Agricultural, Earth and Environmental Sciences, University of KwaZulu-Natal,

Pietermaritzburg, South Africa

\section{CORRESPONDENCE TO: \\ Martin Villet}

EMAIL:

M.Villet@ru.ac.za

\section{POSTAL ADDRESS:}

Department of Zoology and Entomology, Rhodes University, P0 Box 94, Grahamstown 6140, South Africa

\section{DATES:}

Received: 15 Sep. 2013

Revised: 22 Feb. 2014

Accepted: 25 Feb. 2014

\section{KEYWORDS:}

traditional indigenous

knowledge; cultural entomology; folk taxonomy; language policy; lexicographic standardisation; trilingual entomological dictionary

\section{HOW TO CITE:}

Cockburn JJ, Khumalo-Seegelken B, Villet MH. IziNambuzane: IsiZulu names for insects. S Afr J Sci. 2014;110(9/10), Art. \#2013-0292, 13 pages. http://dx.doi.org/10.1590/ sajs.2014/20130292

(C) 2014. The Authors. Published under a Creative Commons Attribution Licence.
We provide a tool for communicating about insects in isizulu to facilitate research and knowledge sharing in the fields of indigenous knowledge, cultural entomology, environmental education and community extension involving isiZulu speakers. A total of 213 different names for 64 insect specimens were encountered among a sample of 67 respondents in 11 communities distributed across the province of KwaZulu-Natal, South Africa. This list includes 93 names that can be considered core isizulu vocabulary and which are widely used to identify insects that are agriculturally, medically, domestically, culturally or ecologically common or significant. Substantial variation was found regarding the names for particular insects, especially between regions, suggesting dialectal differences between isizulu speakers. Grammatical and social variation in names was also recorded. This study highlights interdisciplinary teamwork in the field of indigenous knowledge research and the influences affecting the standardisation of South African languages for technical and scientific work.

'We have really everything in common with America nowadays, except, of course, language.'

Oscar Wilde, The Canterville Ghost (1887)

\section{Introduction}

Research into indigenous knowledge is a fairly new field that aims to connect the knowledge of local communities on one hand and professionals in disciplines including science and community development on the other..$^{1-5} \mathrm{An}$ example is the development of agricultural pest control technology from traditional African farming practices. ${ }^{6}$ As professionals in science and technology start to understand indigenous knowledge systems, they can develop a more accurate and profound understanding of their counterparts in the stakeholder community. In turn, science and technology can become more accessible and more acceptable to the anticipated users. ${ }^{2,45}$ The perception of science and indigenous knowledge as disparate entities, each apparently misunderstood by the other, could be ameliorated by identifying, examining, explaining and evaluating indigenous knowledge. ${ }^{5,7}$ We have deployed these insights in this study in the context of South African entomology by compiling a list of names in the isizulu language (Guthrie Bantoid Language number S428-11) that are used in KwaZulu-Natal to identify insects that are agriculturally, medically, domestically, culturally or ecologically common or significant in that province.

The Constitution of the Republic of South Africa, Act 108 of 1996, recognises 11 official languages, and research into these languages has become a priority. ${ }^{12-14}$ IsiZulu is the home language of about $23 \%$ of South Africans, and is spoken or understood by a substantial percentage of people in all nine provinces in South Africa as their first or second language..$^{15}$ It is most prevalent in KwaZulu-Natal, where about $78 \%$ of the population speaks isizulu as a first language. ${ }^{15}$ It is a Level 4 (Educational) language (http://www.ethnologue.com/language/zul) on the Expanded Graded Intergenerational Disruption Scale $\left(\right.$ EGIDS $\left.^{16}\right)$, which means that literacy in isizulu is being sustained through a system of public education. This indicates a need to gather and formalise indigenous knowledge of terminology in this language, and to compile isizulu texts and standardise vocabulary for use in every field of science and technology in the country (cf. Djitéti3; Mufwene ${ }^{14}$ ). The need for inclusion of indigenous languages and standardisation of names for specific plants and animals for use in environmental research, education and communication in South Africa has been recognised repeatedly (e.g. Feely ${ }^{17}$ ).

Two isizulu language boards - one constituted under the African Languages Board Act of 1977 and the other under the Pan South African Language Board (PanSALB) Act of 1995, in the apartheid and post-apartheid eras, respectively - have made hardly any progress as yet with regard to the standardisation of the language as envisaged by the governments in either era. PanSALB works cooperatively with the Department of Arts and Culture's National Language Service Terminology group, and is actively concerned with lexicography and terminology. In 2001, PanSALB set up new language-specific bodies for each of the official languages, including the isizulu National Language Body. Additionally, a number of grassroots initiatives have formed in response to this need. One of the most inspiring of these is the 'Project for the Study of Alternative Education in South Africa (PRAESA) - Growing biliteracy and multilingualism' (http://www.praesa.org.za). It is our foremost aim in this study to support and contribute to efforts by these bodies and non-governmental grassroots initiatives to systematise and standardise entomological terminology in isizulu.

The names collected during this study were analysed to determine those most frequently used, and to investigate whether different regions have different names for the same insect. The second aim of publishing this study was therefore to provide a tool to enable an enlarged circle of participants, including researchers, scientists, educators and non-professional citizens, to engage more profoundly and effectively in elementary and advanced communication about insects and entomology. Internationally standardised biological nomenclature ('scientific names' ${ }^{\prime 18}$ ) has been used as a frame of reference to minimise ambiguity regarding the identities of the insects and to promote reproducibility in the identification and naming of insects.

English (one of the six EGIDS Level 0 (International) languages, along with Arabic, Chinese, French, Russian and Spanish; http://www.ethnologue.com/) was selected as the language for communicating this study. Even though the proportion of participants and people in general speaking it as a first language at the national level is relatively low (about $8 \%$ ), English has high instrumental value nationally because it is the most commonly widespread and geographically evenly distributed second or third language in the country. It is the language of learning and teaching 
at most South African schools and tertiary educations under the new national education curriculum that makes the teaching of two languages compulsory at school level, and it is the lingua franca both of national government, business and commerce, and of science and education in most parts of post-colonial Africa and abroad..$^{19(0.28)}$ Being able to translate isiZulu entomological names into English gives access to a wealth of entomological information (e.g. Scholtz and Holm's reference work $^{20}$ ) to isizulu speakers. We therefore offer a means to translate between scientific, isiZulu and English names.

\section{Materials and methods}

\section{Sample selection}

Specimens of the 64 insect taxa used by Mkize et al. ${ }^{21}$ to gather isiXhosa names of insects were selected (Table 1). These insects covered a broad range of insect diversity, and included species that are likely to be familiar because they are common or have agricultural, medical, medicinal, cultural or other significance to people. The selection covered the insects included in the children's book by Uys and McLarty ${ }^{22}$ (Table 1), which focuses strongly on taxa of significance to humans, and which might be considered a core set of taxa.

The study was limited to the province of KwaZulu-Natal, South Africa, as it is the area in which the isizulu language originated and is spoken indigenously and where it is therefore likely to be at its purest and least adulterated by other languages. A total of 11 sites was selected throughout the province (Figure 1), representing a compromise between logistical accessibility and geographical coverage. The interview sites can be found at the following localities: Berg Reserves (29'02'54'S,

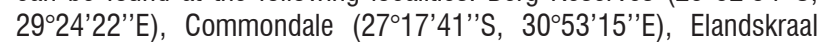

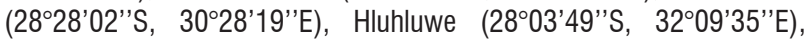

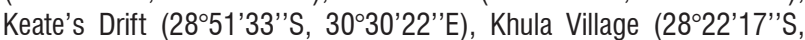

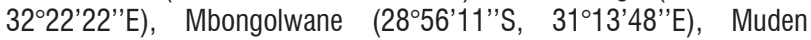

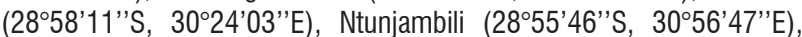

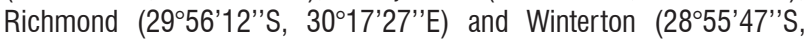
29॰30'03'”E).

Emphasis was placed on selecting respondents in rural communities (who tend to speak 'deep Zulu', isiZulu esijulile; 'high Zulu', isiZulu esiphakeme) over urbanised respondents (who tend to speak urban

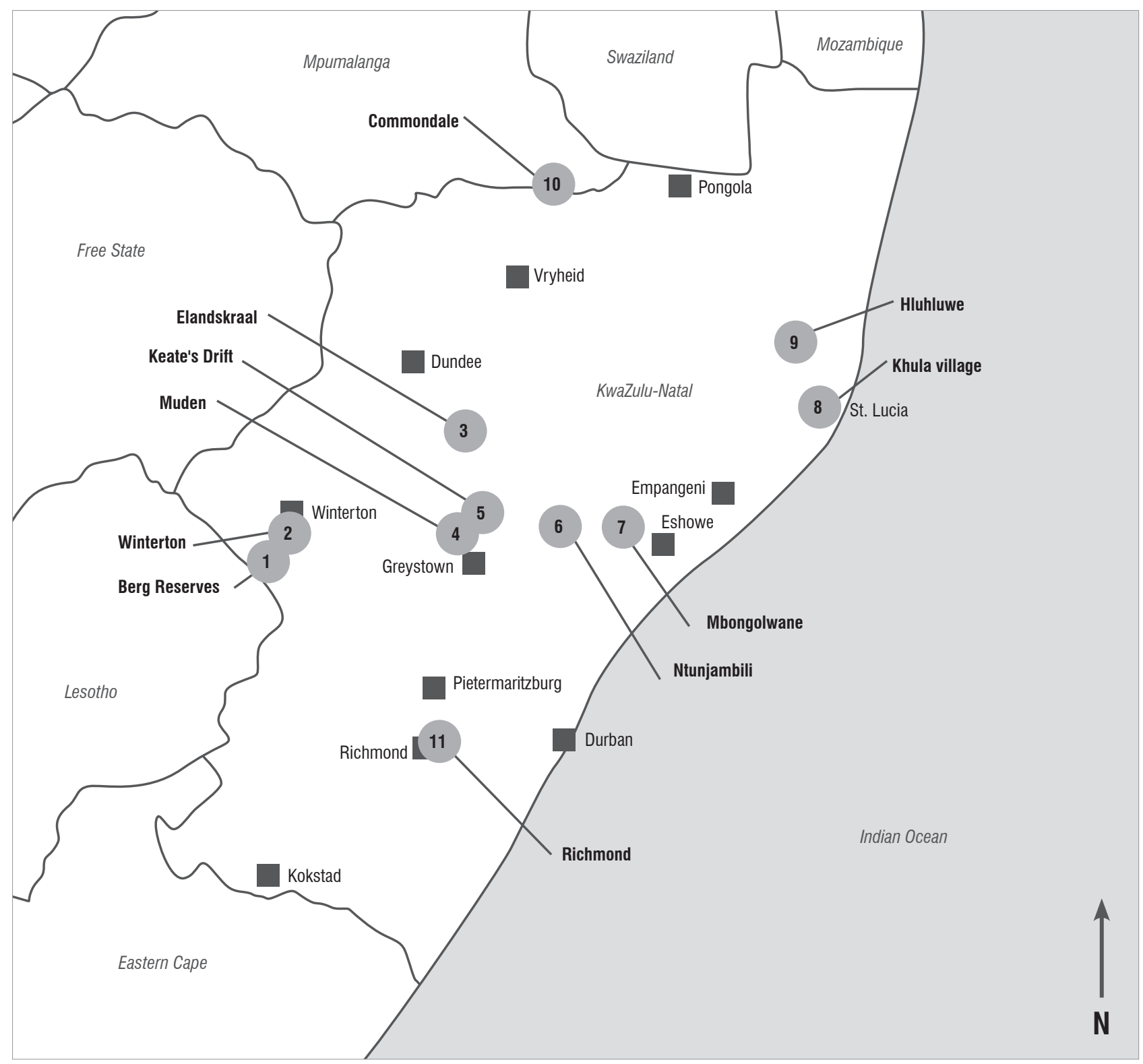

Figure 1: Localities of survey sites. Provinces and neighbouring countries are shown in grey italics; $\boldsymbol{\square}=$ towns; $\bigcirc=$ survey sites, numbered and shown in bold. Exact latitudes and longitudes of the interview sites are provided in the text. 
Table 1: List of insect specimens used in interviews, and of names listed by Doke et al. ${ }^{33}$ and Uys and McLarty ${ }^{22}$. The names are sorted phylogenetically so that entomologists can assess the taxonomic coverage.

\begin{tabular}{|c|c|c|c|c|}
\hline \multicolumn{2}{|c|}{ Scientific name } & \multirow{2}{*}{ English name } & \multicolumn{2}{|l|}{ isiZulu name } \\
\hline Order & Family & & Doke et al. ${ }^{33}$ & Uys and McLarty ${ }^{22}$ \\
\hline Thysanura & Lepismatidae & fishmoth & umvunya wasezincwadini & inyundu yasezincwadini \\
\hline Ephemeroptera & Baetidae & mayfly & (none) & (none) \\
\hline \multirow[t]{2}{*}{ Odonata } & Synlestidae & damselfly & ujekamanzi & (none) \\
\hline & Aeshnidae & dragonfly & ujekamanzi & amazekamanzi \\
\hline Dermaptera & Forficulidae & earwig & umkhothane & umkhothane onezimpondo ezinde \\
\hline \multirow[t]{8}{*}{ Orthoptera } & Grylidae & cricket & inyekevu & isihlonono, udambi \\
\hline & Stenopalmatidae & sand cricket & inyendle & (none) \\
\hline & Tettigoniidae & katydid & igawozi & isilokazane \\
\hline & Acrididae & grasshopper & idiye & amaboni \\
\hline & Pyrogomorphidae & foam grasshopper & intothoviyane & intithoviyane \\
\hline & Pneumoridae & bladder grasshopper & (none) & (none) \\
\hline & Pamphagidae & rain grasshopper (female) & uquqululu & (none) \\
\hline & & rain grasshopper (male) & uquqululu & (none) \\
\hline Phasmatodea & Phasmatidae & stick insect & umtwanawezulu & izintethe ezisanduku \\
\hline Mantodea & Mantidae & praying mantis & isithwalambiza & amaqaqa \\
\hline \multirow[t]{4}{*}{ Blattaria } & Blaberidae & wingless cockroach & igugu & (none) \\
\hline & Blatidae & American cockroach & iphela & amakokoloshe, amaphela \\
\hline & Termitidae & termite (winged) & inhlwa & amaye \\
\hline & & termite (workers) & umuhlwa & amaye \\
\hline Psocodea & Menoponidae & louse & umkhuphe & izintwala \\
\hline \multirow[t]{4}{*}{ Hemiptera } & Aphididae & aphid & i-afidi & izintwala zezimbali \\
\hline & Diaspididae & scale insect & ukhwekhwe Iwezilokazanyana olubulala izithombo & (none) \\
\hline & Cicadidae & cicada & isihlonono & isihlonono esinephiko elisawolintshi \\
\hline & Cimicidae & bedbug & imbungulu & imbungulu yasembhedeni \\
\hline \multirow[t]{9}{*}{ Hymenoptera } & Ichneumonidae & ichneumonid wasp & umuvi & (none) \\
\hline & Pompilidae & spider-hunting wasp & umuvi & umuvi ozingela izicabucabu \\
\hline & Sphecidae & mud wasp & umuvi & umuvi wodaka \\
\hline & Apidae Apinae & honeybee & inyosi & inyosi yoju \\
\hline & Apidae Xylocopinae & carpenter bee & uhlobo olukhulu Iwenyosi ezakhela yodwa & inyosi engumbazi \\
\hline & Vespidae Eumeninae & potter wasp & umuvi & umuvi wodaka \\
\hline & Vespidae Vespinae & paper wasp & umuvi & umuvi wephepha \\
\hline & Formicidae & ant (worker) & itsheketshe & (none) \\
\hline & & thief ant (queen) & (none) & (none) \\
\hline \multirow[t]{15}{*}{ Coleoptera } & Gyrinidae & whirligig beetle & (none) & (none) \\
\hline & Geotrupidae & dung beetle & inkuba & ibhungane elibubende \\
\hline & Scarabaeidae Melolonthinae & Christmas beetle & ibhungane & (none) \\
\hline & Scarabaeidae Dynastinae & rhinoceros beetle & ibhungane & ibhungane elingubhejane \\
\hline & Scarabaeidae Cetoniinae & fruit chafer & ibhungane & ibhungane lezithelo zasengadini \\
\hline & Scarabaeidae Scarabaeinae & dung beetle & inkumablongwe & ibhungane elibubende \\
\hline & Tenebrionidae & toktokkie beetle & umzifisi & ibhungezi limthende \\
\hline & Meloidae & blister beetle & ibhungane & (none) \\
\hline & Lampyridae & glowworm & imfinyezi & imfinyezi kanye nomsundu ocwebezelayo \\
\hline & Elateridae & click beetle & (none) & (none) \\
\hline & Curculionidae & weevil & (none) & (none) \\
\hline & Coccinellidae & ladybird & isilokazana esincane esibomvu esinamachashazi amnyama & ibhungane eliwugugumbe \\
\hline & Cerambycidae & Ionghorn beetle & umpondompondo & (none) \\
\hline & Chrysomelidae Bruchinae & bean weevil & (none) & (none) \\
\hline & Chrysomelidae Cassidinae & tortoise beetle & ibhungane & (none) \\
\hline \multirow[t]{2}{*}{ Neuroptera } & Myrmeliontidae & antlion (adult) & inkunzi yomhlaba & (none) \\
\hline & & antlion (larva) & inkunzi yomhlaba & (none) \\
\hline \multirow[t]{5}{*}{ Lepidoptera } & Psychidae & bagworm (larva) & umahambanendlwana & umahambanendlwana \\
\hline & Sphingidae & hawk moth & uvemvane & inyundu enombala osasiliva okufana noklebe \\
\hline & Noctuidae & owlet moth & uvemvane & izinyundu \\
\hline & Papillionidae & citrus swallowtail & uvemvane & izivemvane \\
\hline & Pieridae & white butterfly & uvemvane & izivemvane \\
\hline \multirow[t]{8}{*}{ Diptera } & Tipulidae & crane fly & (none) & umlenzemide \\
\hline & Culicidae & mosquito & umiyane & umiyane \\
\hline & Asilidae & robber fly & (none) & impukane eyisigebengu \\
\hline & Syrphidae & hover fly & inyosi & (none) \\
\hline & Muscidae & house fly & impukane & impukane yasendlini \\
\hline & Sarcophagidae & flesh fly & impukane & (none) \\
\hline & Calliphoridae & bluebottle fly & imvimvi & (none) \\
\hline & & greenbottle fly & imvimvi & (none) \\
\hline Siphonaptera & Pulicidae & flea & izeze & amazeze \\
\hline
\end{tabular}


Zulu, isizulu sasedolobheni) because traditional indigenous knowledge is generally believed to be retained better in rural areas than in urban settings. ${ }^{21,23}$ In total, 67 people were interviewed, five to eight from each site (Table 2). Older respondents were chosen preferentially, as one might expect them to have accumulated a greater knowledge of insects' names. ${ }^{21}$

\section{Data collection}

Various isizulu speakers familiar to particular local communities accompanied the interviewer (JJC) to introduce them to the prospective respondents, to facilitate the observation of appropriate local etiquette, and to interpret, explain and clarify where necessary. The interviewer also spoke isizulu, which contributed to normalising the situation and promoting communication. To expose potential methodological problems, two pilot interviews were conducted before commencing data collection..$^{24,25}$ The study was approved by the Department of Zoology and Entomology, Rhodes University.

In adherence to the principle of observing and respecting the dignity and privacy of each interviewee, interviews started with explaining the goals of the interview and asking permission to continue. ${ }^{25-27}$ Relevant biographical details including age, education and employment were recorded on questionnaire sheets by the interviewer if the respondent was explicitly willing to share that information. Ten of the respondents were nature conservation personnel, who could be expected to have a more detailed and accurate knowledge of insects' names because of their apparently greater interest in, or exposure to, nature. This subset of respondents was also analysed separately to provide qualitative crossvalidation of the list of isizulu names.
Each respondent was then asked to identify the preserved specimens of insects (Table 1), and to share any additional information about each insect, e.g. its agricultural, medical, domestic, cultural or other significance. The insects were selected for their ubiquity or significance to humans. The specimens were each numbered for ease of reference and data capture and placed in wooden field boxes suitable for travelling. Several strategies were used to increase the quality of the interview data. One interviewer (JJC) carried out all of the interviews to promote uniformity. Respondents were interviewed individually whenever possible to ensure independence of opinion, although this was not always possible as a result of local etiquette and custom. Leading questions and questions with yes/no answers were avoided, and interviewees were given opportunity to expand freely on their basic identification by giving additional information. ${ }^{24,26-29}$ The use of names of insects in other languages (isiXhosa, seSotho, English, etc.) were avoided during interviews to forestall potential sources of confusion.

Spelling was transcribed phonetically by the interviewer in consultation with the accompanying isizulu translator using the standard Roman notation for isizulu click consonants ( $c=1$, dental click; $q=$ !, alveolar click; $x=\|$, [bi]lateral click) and alveolar lateral fricatives $(\mathrm{hl}=\mathrm{q}$, voiceless; $d l=13$, voiced) (http://isizulu.net/p11n/).

\section{Analysis and cross-validation}

The profiles of respondents were summarised with simple descriptive statistic ${ }^{25}$ and bivariate linear regression.

The completeness of the sample, at least for KwaZulu-Natal, was assessed using sample accumulation curves ${ }^{30,31}$ and a responsefrequency histogram ${ }^{32}$ was constructed to explore how the names could

Table 2: $\quad$ Biographical profiles of amaZulu respondents in 11 communities located in KwaZulu-Natal (Figure 1)

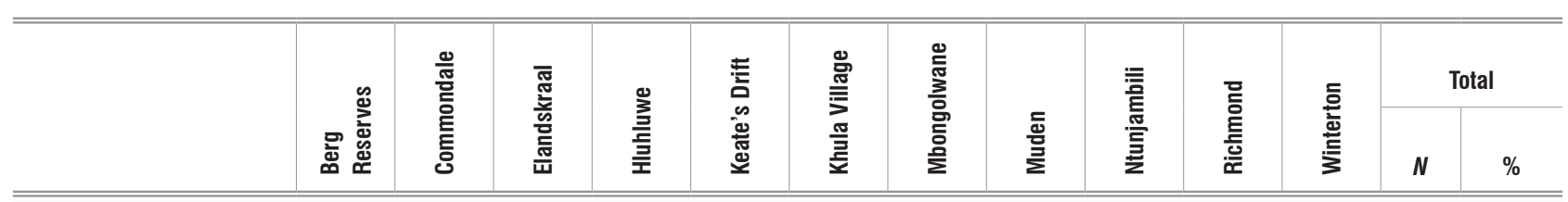

\section{Number of respondents}

\begin{tabular}{|c|c|c|c|c|c|c|c|c|c|c|c|c|c|}
\hline Total & 5 & 7 & 6 & 8 & 6 & 5 & 7 & 6 & 5 & 6 & 6 & 67 & 100 \\
\hline Women & 0 & 2 & 3 & 5 & 3 & 3 & 3 & 5 & 3 & 0 & 4 & 31 & 46 \\
\hline Men & 5 & 5 & 3 & 3 & 3 & 2 & 4 & 1 & 2 & 6 & 2 & 36 & 54 \\
\hline
\end{tabular}

Age group (years)

\begin{tabular}{l|l|l|l|l|l|l|l|l|l|l|l|l|l|}
\hline $20-39$ & 2 & 1 & 3 & 2 & & & 4 & 1 & 13 \\
\hline $40-59$ & 1 & 4 & 2 & 2 & & 2 & & 1 & 1 & 1 & 5 & 19 & 28 \\
\hline $60-69$ & 2 & 1 & 1 & 2 & 6 & 3 & 1 & 1 & 4 & 4 & 1 & 26 & 39 \\
\hline $70+$ & & 1 & & 2 & & & 2 & 3 & 1 & \\
\hline & & & & & & & & & & \\
\hline
\end{tabular}

Formal education

\begin{tabular}{|c|c|c|c|c|c|c|c|c|c|c|c|c|c|}
\hline Undisclosed & & 1 & & & & & & & & & & 1 & 1.5 \\
\hline None & & 1 & 6 & 4 & 4 & 5 & 3 & 4 & 2 & 5 & 4 & 38 & 57 \\
\hline Primary & 3 & 3 & & 2 & 1 & & & 1 & 3 & 1 & 2 & 16 & 24 \\
\hline Secondary & 2 & 2 & & 1 & 1 & & 4 & 1 & & & & 11 & 16 \\
\hline Tertiary & & & & 1 & & & & & & & & 1 & 1.5 \\
\hline
\end{tabular}


be simplistically categorised into personal, local and standard names according to how many people reported them ${ }^{21}$. When a name was reported by only two respondents who were interviewed at the same time, they were deemed to be non-independent samples and were classified as personal names for this study. When a name was reported by only two respondents but they were from distant sites, these names were regarded as rare knowledge rather than personal names; four such names were encountered.

Two additional published sources of insect names in isizulu were consulted to further gauge the completeness of the sample and for comparative purposes: an English-Zulu Zulu-English Dictionary ${ }^{33}$ and a children's book on invertebrates, My First Book of Southern African Creepy-Crawlies ${ }^{22}$, which included isizulu names (Table 1).

\section{Results and discussion}

\section{Respondents' profiles}

Many people were willing and even enthusiastic to be respondents. The occupational backgrounds of the selected respondents included induna (1 person), councillor (2), farmer (2), homekeeper (14), farmworker (7), security guard (1), shopkeeper (1), teacher (1), nature conservation personnel (10), traditional healer (1), variously employed (17) and unemployed (10). Over half (57\%) of the respondents had no formal education and only $11 \%$ had formal education above primary level (Table 2), implying that few of the respondents might have learned 'standard' names from such formal sources. Respondents provided 1838 names each, and on average an individual knew 28 names. The same name was often indicated for more than one specimen by an individual. No one could name every specimen; individual respondents identified an average of $8(0-18)$ specimens as familiar but did not know a name for them, and $7(0-17)$ specimens as unknown to them, indicating that it was unlikely that respondents made up names during the interviews.

About $53 \%$ of the respondents were over 60 years of age (Table 2 , Figure 2). Contrary to expectations, there was no overall correlation between a respondent's age and the size of their reported entomological vocabulary, irrespective of gender (Table 3). Younger men tended to report significantly more names, primarily in the non-personal category. While older women tended to report proportionately more personal names (Figure 2), this was not statistically significant (Table 3). Many of the respondents mentioned that they learned insects' names while playing in the fields as children and could only barely remember some of them because they have not had much contact with them since their childhoods.

Table 3: Pearson's correlation coefficients for the relationship between respondents' ages and the numbers of names they reported. Correlations set in bold are statistically significant at $\alpha=0.05$.

\begin{tabular}{l|c|c|c}
\hline \hline & All names & $\begin{array}{c}\text { Non-personal } \\
\text { names }\end{array}$ & Personal names \\
\hline \hline Women & 0.122848 & 0.025456 & 0.194084 \\
\hline Men & -0.387923 & -0.337790 & -0.239872 \\
\hline All & -0.166607 & -0.188450 & -0.028460 \\
\hline
\end{tabular}

Only three respondents were living more than $60 \mathrm{~km}$ from their place of birth, so migration was unlikely to have introduced allochthonous dialectal names to a site.

\section{Completeness of sample}

In total, 213 names were collected. A sample accumulation curve constructed without permutation (Figure 3a) shows that the number of interviews (5-8) at each site was sufficient to represent each site because the curves flattened off within each site. When names classified as personal (i.e. reported by only one person, or two people in the same interview) were excluded, the unpermuted sample accumulation curve indicated that there were 93 non-personal names, and that the sample was adequate. A response-frequency histogram (Figure 4) suggested that about five more non-personal names might be found. In the 6 years subsequent to our field work, we discovered only one more name - isihlava - which is used widely for stem borers (Lepidoptera: Noctuidae) that attack maize and sugar cane. ${ }^{34}$ In areas north and northeast of the Thukela River and northeast of the Phongolo River, isiZulu speakers call dragonflies (Odonata) ibhebhamanzi or amabhebhamanzi, but these terms were not reported to the interviewers, apparently because they are considered impolite.

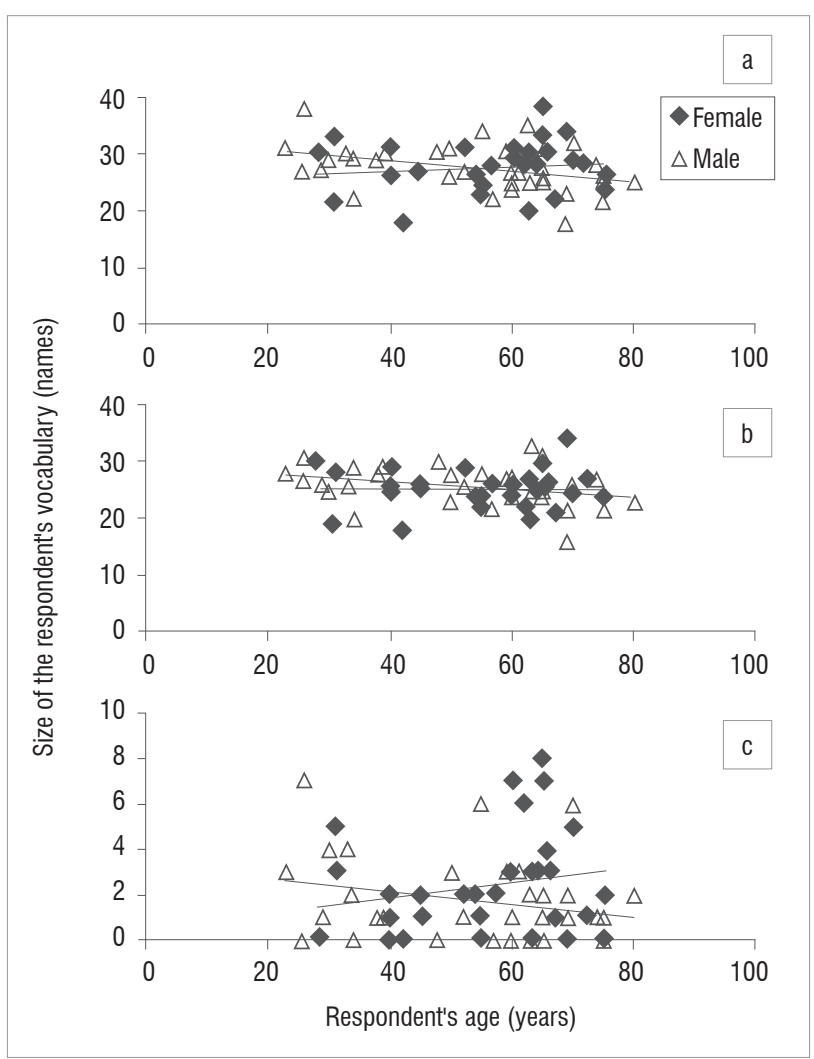

Figure 2: Relationships between age and vocabulary size of respondents in terms of (a) all names, (b) non-personal names and (c) personal names. The trend lines reflect the correlations reported in Table 3.

Comparing the sample accumulation curve of this study with that of a sample of isiXhosa names for the same insects, ${ }^{21}$ there are fewer nonpersonal names (93) in isizulu, whereas for the isiXhosa study the curve appeared to be reaching a plateau at about 116 non-personal names. The study of isiXhosa involved only eight sites and 51 respondents. ${ }^{21}$

Interviewing nature conservation personnel did not elicit a greater number of names (an average of 49 names versus an average of 50 names from other respondents; two-tailed $t$-test with unequal variances, $t=0.65 ; p=0.524$ ), nor did the respondents contribute a set of words that was much different from that provided by other respondents. This finding indicated that such specialists would not be a useful source against which to check for errors, perhaps because most of them were in the younger age groups. The respondents who seemed to impart the greatest knowledge of insects with the most confidence were elderly women who had been farmers all their lives.

Of the names collected in the present study, $56 \%$ matched the names of Doke et al. ${ }^{33}$ either exactly or with some qualification (i.e. variations in pronunciation [ $=$ spelling] or grammar or by the addition of descriptive phrases) (Table 4). The total percentage of matches with the list of names of Uys and McLarty ${ }^{22}$ was lower (36\%), and $59 \%$ of the names in that list had no match with those in the present study. The lists of names from Doke et al. ${ }^{33}$ and Uys and McLarty ${ }^{22}$ both include descriptive names of insects, i.e. lengthy phrases which describe the insects but are unlikely to be a standardised name for that insect in isizulu (Table 1). 


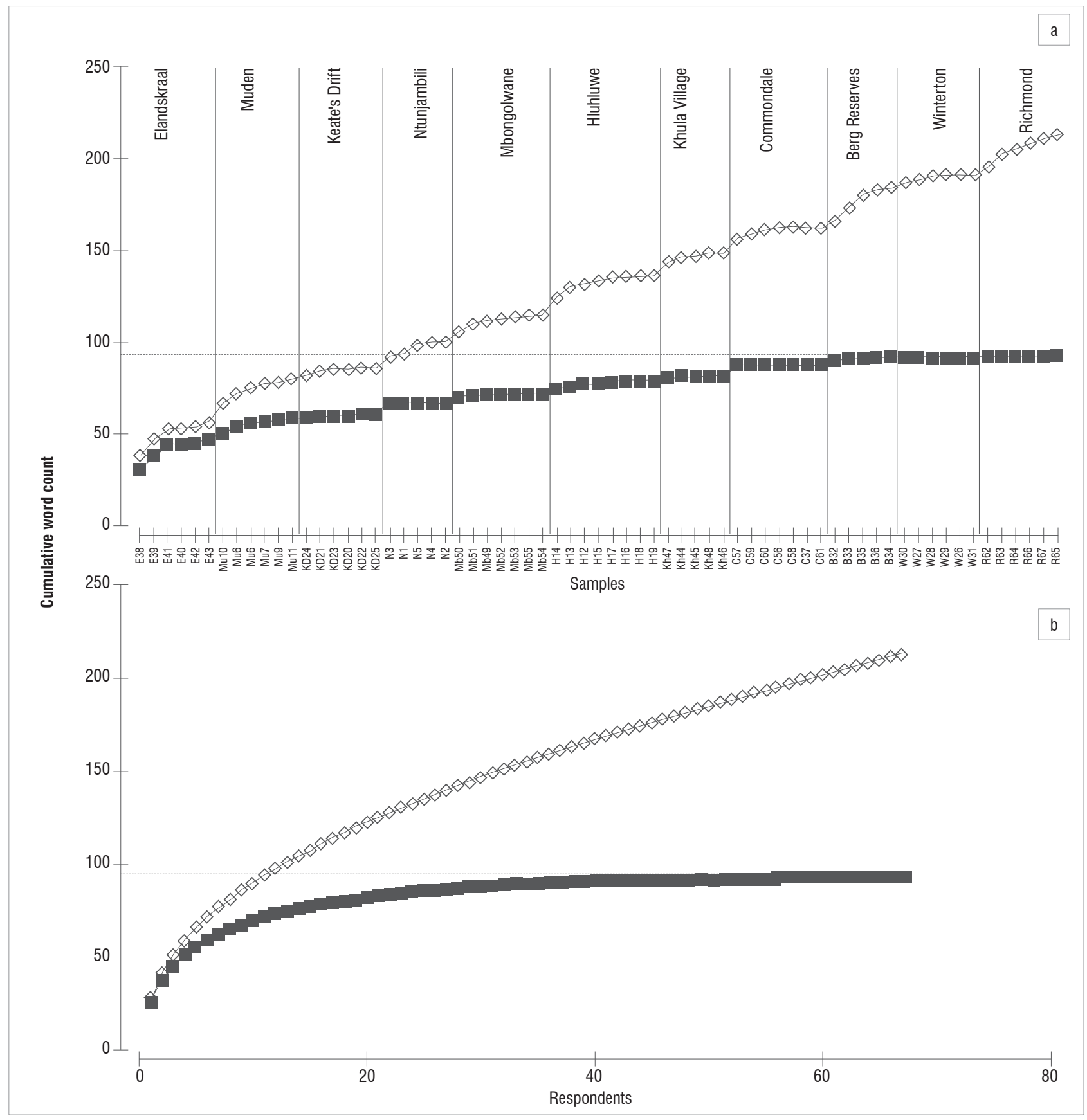

Figure 3: (a) Sample-accumulation curves constructed without permutation of samples. The flattening of the curves within each locality indicates that they are adequately surveyed. (b) Sample-accumulation curves constructed using 999 sampling permutations, used to estimate how many isizulu entomological names there may be. The sample of non-personal names (i.e. those reported by at least two respondents from different sites; solid symbols) reaches an apparent asymptote at 93 names (dotted line), while the sample is still growing when personal names (i.e. names reported by only one respondent) are included.

We interpret these statistics collectively to mean that a sufficiently large sample had been collected here for a substantial list of reliable names to be compiled confidently and for the further inference of interesting patterns.

\section{Patterns of variation}

A quarter of the names (56 names, 26\%) are 'general' names known by more than seven respondents and are widespread across all regions and all communities (Figure 4), and may be interpreted as core vocabulary in isizulu. Another 37 'local' names (Figure 4), defined as names known by two to eight respondents from neighbouring sites, ${ }^{21}$ were responsible for much of the small, sharp 'leaps' in numbers in the sample accumulation curve (Figure 3a), and for $17 \%$ of the names. These names are particularly characteristic of the Richmond site, which has one name (unogwensi) used by all respondents from this site, but which was not used at any other site, and three more names used almost exclusively at this site and by most of its respondents.

A total of 120 names were classified as 'personal', known by only one or two (non-independent) respondents (Figure 4), and the sample accumulation curves (Figure 3 ) did not provide an estimate of the potential total. Bryant ${ }^{35}$ also noted that people using Bantoid languages have, like many other language families elsewhere, shown a high degree 
of inventiveness and ingenuity in sculpting their languages. Personal names were not evenly distributed amongst the respondents, but were over-represented among older women and younger men (Figure 2). A potential explanation for this pattern lies in the amaZulu tradition of ukuhlonipha, the respectful avoidance of speaking the names, or even syllables of the names, of significant people such as elders, leaders or in-laws. ${ }^{36-38}$ When a speaker needs to use a name affected by this tradition, they must substitute a different syllable or pick a replacement name. Such individualised creativity can be expected to particularly affect the names used by older women (with more relatives by marriage) and younger men (with relatively more seniors), relative to their counterparts, and therefore fits the pattern in Figure 2. Unfortunately, we could not follow up this speculation.

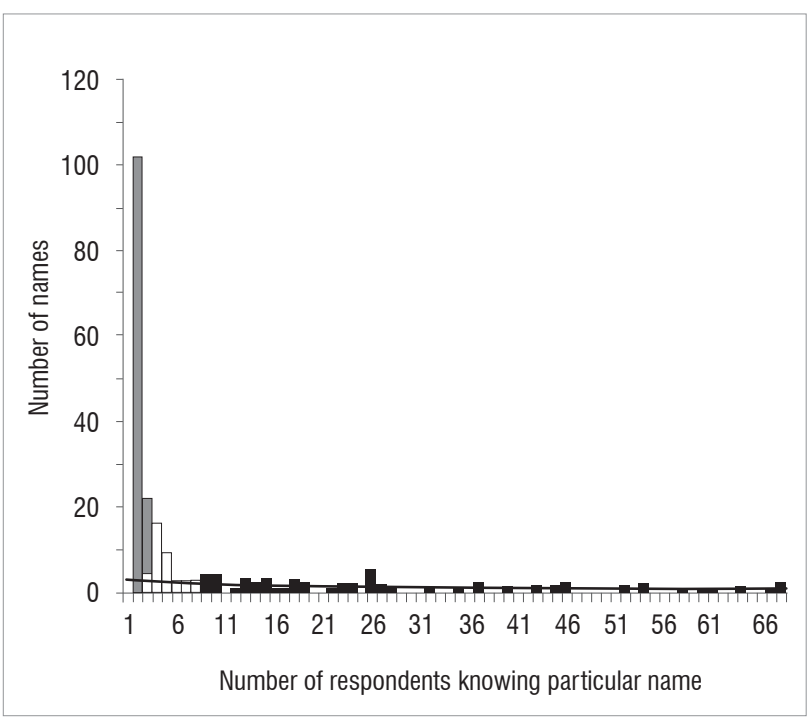

Figure 4: Response-frequency histogram used to estimate that about five cosmopolitan isizulu names for insects are yet to be 'discovered'. The black histogram bars represent cosmopolitan names, and the point at which the black line fitted to them intersects with the $y$-axis provides an estimate of how many names are known by 0 people in the sample, i.e. await 'discovery'.

Table 4: Comparison of isizulu insect names collected in the present study with two reference sources of names

\begin{tabular}{l|c|c}
\hline \hline Number of names in lists & Doke et al. ${ }^{33}$ & $\begin{array}{c}\text { Uys and } \\
\text { McLarty22 }\end{array}$ \\
\hline \hline Exact matches & $34(53 \%)$ & $8(13 \%)$ \\
\hline Near matches (spelling or other variation) & $2(3 \%)$ & $15(23 \%)$ \\
\hline Inexact matches (different taxa) & $6(9 \%)$ & $3(5 \%)$ \\
\hline No match & $22(34 \%)$ & $38(59 \%)$ \\
\hline
\end{tabular}

There is also a great deal of variation in the grammatical structure of the isizulu words for insects, which has also been noted for isizulu plant names. ${ }^{39}$ For example, dragonflies (Odonata: Anisoptera) are most commonly indicated by the stem -jekamanzi, but the prefix (and therefore the noun class) of this varies depending on the geographical region in focus. The prefixes isi- (plural izi-) and $u$ - (plural 0 -) were found to be used with the stem -jekamanzi (Tables 5, 6). Grammatically, isizulu birds' names can be classified into three categories according to the structure of the word stem, namely single-, complex- and compoundstemmed names. ${ }^{40}$ Amongst the insects' names, examples of each of these categories of names can also be found: simple-stemmed name: idiye (Orthoptera: Acrididae: grasshopper); complex-stemmed name: umayifisa (Coleoptera: Tenebrionidae: toktokkie beetle); and compound-stemmed name: imfundamakhwela (Coleoptera: Gyrinidae: whirligig beetle).

Finally, there may be social differentiation in the use of names for insects. Although not reported by the respondents, alternative names may be given to insects by children, boys and girls alike, for example ufudu (which means 'tortoise' in English) for tortoise beetles (Coleoptera: Chrysomelidae: Cassidinae), which adults would call umanqolwane (BKS, personal observations). Parallel examples occur in other languages, e.g. in Hausa (e.g. little girls' kabar mazaa daddahee versus adults' adinidma for locust') and in English (children's 'bow-wow' versus adults' 'dog').

\section{Taxonomic resolution}

Attempts to compare non-scientific naming systems (often termed 'folk taxonomies ${ }^{\prime 4,5,41,42}$ ) such as those found in isizulu or English with any terminological systems of biological nomenclature have ultimately been rejected as ineffective and undesirable. This situation is especially true when it comes to trying to promote and support interrelated networks of knowledge systems within a given context in post-colonial Africa. ${ }^{43}$ Speakers of an indigenous African language like isizulu perceive and experience such attempts as biased, presumptuous and exclusively Eurocentric. ${ }^{44,45}$ Penel $^{7}$ noted that the biggest difference between the two knowledge systems, in his case between the nomenclature of the non-Bantoid Hausa language of Niger and Nigeria and Linnean biological nomenclature, is that the latter is divided into genus and species, and Hausa names are not. This is also true for isizulu and English names. The Linnean system is also hierarchical, nested and governed by an internationally mandatory, bilingual, published code, ${ }^{18}$ and is generally practised in an explicitly phylogenetic framework, all of which distinguish it from folk taxonomies.

An example of the incommensurability of isizulu folk taxonomy and biological nomenclature is the term izinambuzane, which refers to insects in general, but is also applied to moles and cane rats in some areas (JJC, personal observations). However, there are some parallels between names in isizulu and the ranks of Linnean classification. It appears that isizulu names do not go beyond the taxonomic resolution of family-level identification, and are more easily comparable to names accorded the Linnean taxonomic rank of 'order'. For example, ujekamanzi corresponds to the order Odonata (dragonflies and damselflies), ibhungane / ibhungezi / ibhungayezi to the Coleoptera (beetles sensu stricto), depending on which region the speaker is in, and umnyovu / umuvi to the Hymenoptera (wasps, but excluding ants and bees). This taxonomic resolution does vary though; for example, the order Diptera (flies) is not given one general name, but is rather sub-divided into umiyane / unongxi for mosquitoes (of the family-ranked taxon Culicidae) and impukane for blow flies and house flies (families Calliphoridae and Muscidae, respectively). This pattern seems to indicate that more specific names are given to insects which are of particular intimate significance, for example honeybees, mosquitoes and house flies. A similar pattern is seen in other languages, including English and isiXhosa. ${ }^{21}$

It is not clear to what extent misidentification is involved here, but there is some evidence of it. For example, the hoverfly (Diptera: Syrphidae) was often named inyosi, the name given to honeybees (Hymenoptera: Apidae: Apis mellifera) (Tables 1, 5, 6), presumably because hoverflies mimic honeybees sufficiently well to confuse observers even though they have only one pair of wings like other flies. Crane flies, robber flies and antlions were all referred to as ujekamanzi (Tables 5, 6), although the reference to water (-manzi) in that name clearly aligns it with the biology of the dragonflies and damselflies that it also denotes (Tables 5, 6). However, all of these specimens were large, with elongated abdomens and clear wings, so ujekamanzi may be understood to designate a physical form rather than a specific taxon, in analogy to the terms 'pest' and 'bug' and 'germ' in English folk taxonomy, inunu in isizulu or gogga in Afrikaans.

Names that indicate insects at the species level refer to particular insect species that have intimate contact with the lives of isizulu speakers. For example, honeybees (Hymenoptera: Apidae: Apis mellifera), greenbottle 
Table 5: Dominant isizulu entomological names collected from interviews. 'isizulu name 1' refers to the most common name per specimen across all regions and 'isizulu name 2' refers to the second most common name across all regions (where this differs from isizulu name 1 and is known by five or more people). '-' indicates that no isizulu name showed consistency (fewer than five people knew the name), often because that particular insect was not known to the respondents.

\begin{tabular}{|c|c|c|c|c|}
\hline \multirow{2}{*}{ English name } & \multicolumn{2}{|c|}{ isiZulu name 1} & \multicolumn{2}{|c|}{ isiZulu name 2} \\
\hline & Singular & Plural & Singular & Plural \\
\hline ant & itsheketshe & amatsheketshe & intsheketshe & amantsheketshe \\
\hline ant, thief $\sim$ (queen) & ihlwabisi & amahlwabisi & umnyovu & iminyovu \\
\hline antlion (adult) & ugogo & ogogo & - & - \\
\hline antlion (larva) & ujekamanzi & ojekamanzi & - & - \\
\hline aphid & - & - & - & - \\
\hline bagworm & umahambanendlwane & omahambanendlwane & - & - \\
\hline bee, carpenter & ibhungezi & amabhungezi & ibhungane & amabhungane \\
\hline bee, honey & inyosi & izinyosi & - & - \\
\hline beetle, blister & ibhungezi & amabhungezi & ibhungane & amabhungane \\
\hline beetle, Christmas & ibhungezi & amabhungezi & ibhungane & amabhungane \\
\hline beetle, click & ibhungezi & amabhungezi & - & - \\
\hline beetle, dung & ibhungezi & amabhungezi & ibhungane & amabhungane \\
\hline beetle, dung & ibhungezi & amabhungezi & ibhungane & amabhungane \\
\hline beetle, longhorn & umzondo & imizondo & - & - \\
\hline beetle, rhinoceros & ibhungezi & amabhungezi & ibhungane & amabhungane \\
\hline beetle, toktokkie & ibhungezi & amabhungezi & ibhungane & amabhungane \\
\hline beetle, tortoise & - & - & - & - \\
\hline beetle, weevil & ibhungezi & amabhungezi & umayifisa & omayifisa \\
\hline beetle, whirligig & imfundamakhwela & izifundamakhwela & - & - \\
\hline bug, bed & imbungulu & izimbungulu & - & - \\
\hline butterfly, citrus swallowtail & uvemvane & izimvemvane & ivemvane & amavemvane \\
\hline butterfly, white & uvemvane & izimvemvane & ivemvane & amavemvane \\
\hline cicada & isihlonono & izihlonono & - & - \\
\hline cockroach, American & iphela & amaphela & igugu & amagugu \\
\hline cockroach, wingless $\sim$ & igugu & amagugu & - & - \\
\hline cricket & inyekevu & inyekevu & inyendle & izinyendle \\
\hline cricket, sand & inyendle & izinyendle & - & - \\
\hline damselfly & ujekamanzi & ojekamanzi & - & - \\
\hline dragonfly & ujekamanzi & ojekamanzi & isijekamanzi & izijekamanzi \\
\hline earwig & umkhothane & imikhothane & umbhelekendlane & imibhelekendlane \\
\hline fishmoth & ubuthethe & ubuthethe & - & - \\
\hline flea & izenze & amazenze & izeze & amazeze \\
\hline fly, bluebottle & impukane & izimpukane & - & - \\
\hline fly, crane & ujekamanzi & ojekamanzi & - & - \\
\hline fly, flesh & impukane & izimpukane & isibawu & izibawu \\
\hline fly, greenbottle & impukane & izimpukane & - & - \\
\hline fly, house $\sim$ & impukane & izimpukane & - & - \\
\hline fly, hover & inyosi & izinyosi & - & - \\
\hline fly, mosquito & umiyane & omiyane & unonxi & ononxi \\
\hline fly, robber & ujekamanzi & ojekamanzi & - & - \\
\hline fruit chafer & ibhungezi & amabhungezi & ibhungane & amabhungane \\
\hline glowworm & imfinyezi & izimfinyezi & ukhanyikhanyi & okhanyikhanyi \\
\hline grasshopper & iboni & amaboni & idiye & amadiye \\
\hline grasshopper, bladder & intothoviyane & izintothoviyane & - & - \\
\hline grasshopper, foam & intothoviyane & izintothoviyane & intethe & izintethe \\
\hline grasshopper, rain $\sim$ (female) & ugqugqululu & ogqugqululu & isihlonono & izihlonono \\
\hline grasshopper, rain $\sim$ (male) & ugqugqululu & ogqugqululu & isihlonono & izihlonono \\
\hline katydid & intethe & izintethe & igawozi & amagawozi \\
\hline ladybird & ibhungezi & amabhungezi & - & - \\
\hline louse & ubukhuphe & ubukhuphe & intwala & izintwala \\
\hline mayfly & umniyane & omniyane & - & - \\
\hline moth, hawk & uvemvane & izimivemvane & ivemvane & amavemvane \\
\hline moth, owlet & uvemvane & izimvemvane & isiphaphalazi & iziphaphalazi \\
\hline praying mantis & isithwalambiza & izithwalambiza & umashisindlu & omashisindlu \\
\hline scale insect & - & - & - & - \\
\hline stick insect & isithwalambiza & izithwalambiza & - & - \\
\hline termite (winged) & inhlwabusi & izinhlwabusi & inkulungwane & obhobholwane \\
\hline termite (worker) & umuhlwa & imihlwa & - & - \\
\hline wasp, ichneumonid & - & - & - & - \\
\hline wasp, mud & umnyovu & iminyovu & umuvi & imivi \\
\hline wasp, paper & umnyovu & iminyovu & - & - \\
\hline wasp, potter & umnyovu & iminyovu & - & - \\
\hline wasp, spider-hunting & umnyovu & iminyovu & - & - \\
\hline weevil, bean $\sim$ & imbovane & izimbovane & impehlwa & imiphehlwa \\
\hline
\end{tabular}


flies (Diptera: Calliphoridae) and bedbugs (Hemiptera: Cimicidae: Cimex lectularius) are well known by the majority of respondents and each have one universal name (Figure 5). The honeybee is known for its honey and its sting; the greenbottle fly for frequently infecting food and cattle's wounds; and the bedbug for uncomfortable bites. These names are amongst the most geographically universal, which is an interesting correlation that is very convenient for practical reasons, especially in applied entomology.

\section{Linguistic standardisation}

As in isiXhosa, in which over half of the insects had more than one name, ${ }^{21}$ isizulu may have several names for the same insect, which poses a potential challenge for proponents of the linguistic standardisation of this dynamic language. To decide which name was dominant, and whether there was enough consistency within the sample to assign one dominant name to an insect, i.e. if a name is culturally stable, we used the criterion that a name must be known by at least five people throughout the sample (i.e. $10 \%$ ). Table 5 provides the apparent core list of isizulu names for insects compiled under this criterion. For some insects, no consistent name could be recorded and it was therefore conservatively assumed that the name was not agreed by the respondents we interviewed.

As highlighted by the response-frequency histogram (Figure 4), there is some regionalism that cannot be ascribed to differences in the local faunas because the interviews were standardised by using the same set of specimens. For the regional list (Table 6), the most common name must be known independently by at least two people in that community. Independent use of a name within a community by more than two people, which was not mentioned in other areas, clearly illustrates how different names are used in different areas. For example, in most of the regions surveyed, the word izenze was used for flea (Siphonaptera) but in the area southeast of the Drakensberg and northwards to northeast of the Thukela River, the word izeze was more common (Figure 6). Fortunately, the regional names are not mutually exclusive, and an isizulu-speaker anywhere will understand both izeze and izenze. The case of ujekamanzi and ibhebhamanzi is mentioned above. These examples are most likely a form of dialect, which is described by Kaschula and Anthonissen ${ }^{46}$ as mutually intelligible forms of a language that differ systematically across geographical or social gradients. According to the literature, two to four dialects are usually attributed to isizulu, including isizulu phaqa (proper Zulu), isizulu sasezansi (south Zulu) and isiZulu sasemadolobheni (urban Zulu) spoken north and south of the Thukela River (Guthrie number S42A), isiZulu saseGoli, Transvaal Zulu (S42B), and perhaps the extinct Lala (S406). ${ }^{8-11}$

However, not all geographical variants are as similar as these examples, and some regions show an overlap in regional names that are less likely to represent mutually intelligible dialectal variation. For example, at Mbongolwane, almost as many respondents called butterflies (Lepidoptera: Papilionidae and Pieridae) isiphaphalazi as called them uvemvane. Mbongolwane lies between sites northeast of the Thukela River (Hluhluwe, Khula Village) that use isiphaphalazi and sites southeast of the Thukela River (Muden, Ntunjambili, etc.) that favour uvemvane. Such differences mark the onset of development of dialects into separate languages.

Linguistic standardisation is part of the mandate of the Pan South African Language Board, which must reconcile its aims with all of these aspects of diversity and evolution in isizulu entomological names, which also occur in isizulu ornithological names ${ }^{40}$, isizulu botanical names ${ }^{39}$, isiXhosa entomological names ${ }^{21}$, folk taxonomies worldwide and language in general. Traditionally, dictionaries have been seen by their users (and often also their writers) as arbiters of standardised usage and spelling, thus accorded a prescriptive role. Modern lexicography recognises that languages are dynamic and evolutionary, an insight that has led to dictionaries becoming linguistically descriptive, rather than prescriptive, ${ }^{47}$ but they can still be compiled for linguistic standardisation agendas.

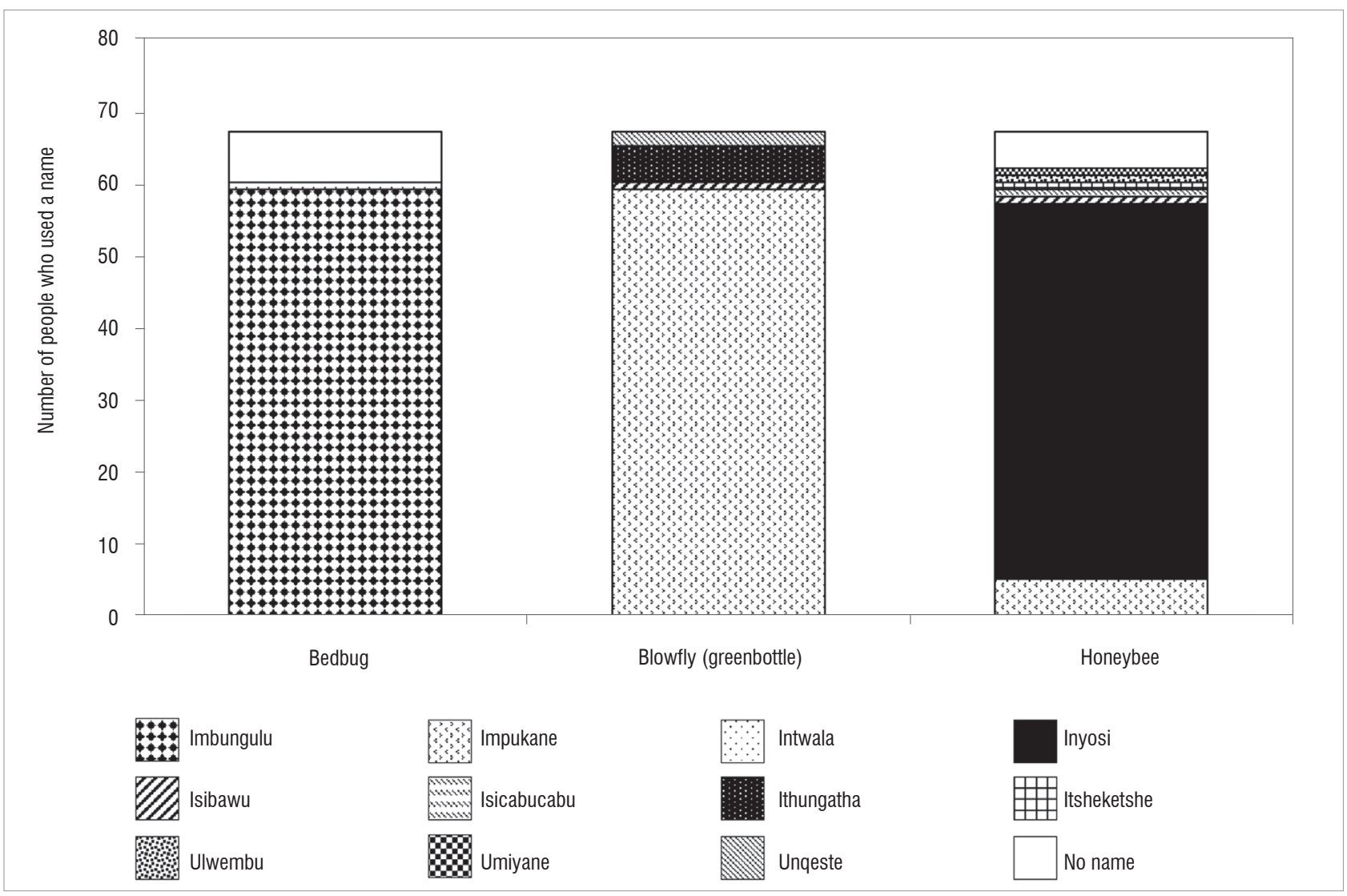

Figure 5: Examples of insects that have one cosmopolitan name that is used consistently across all regions. 


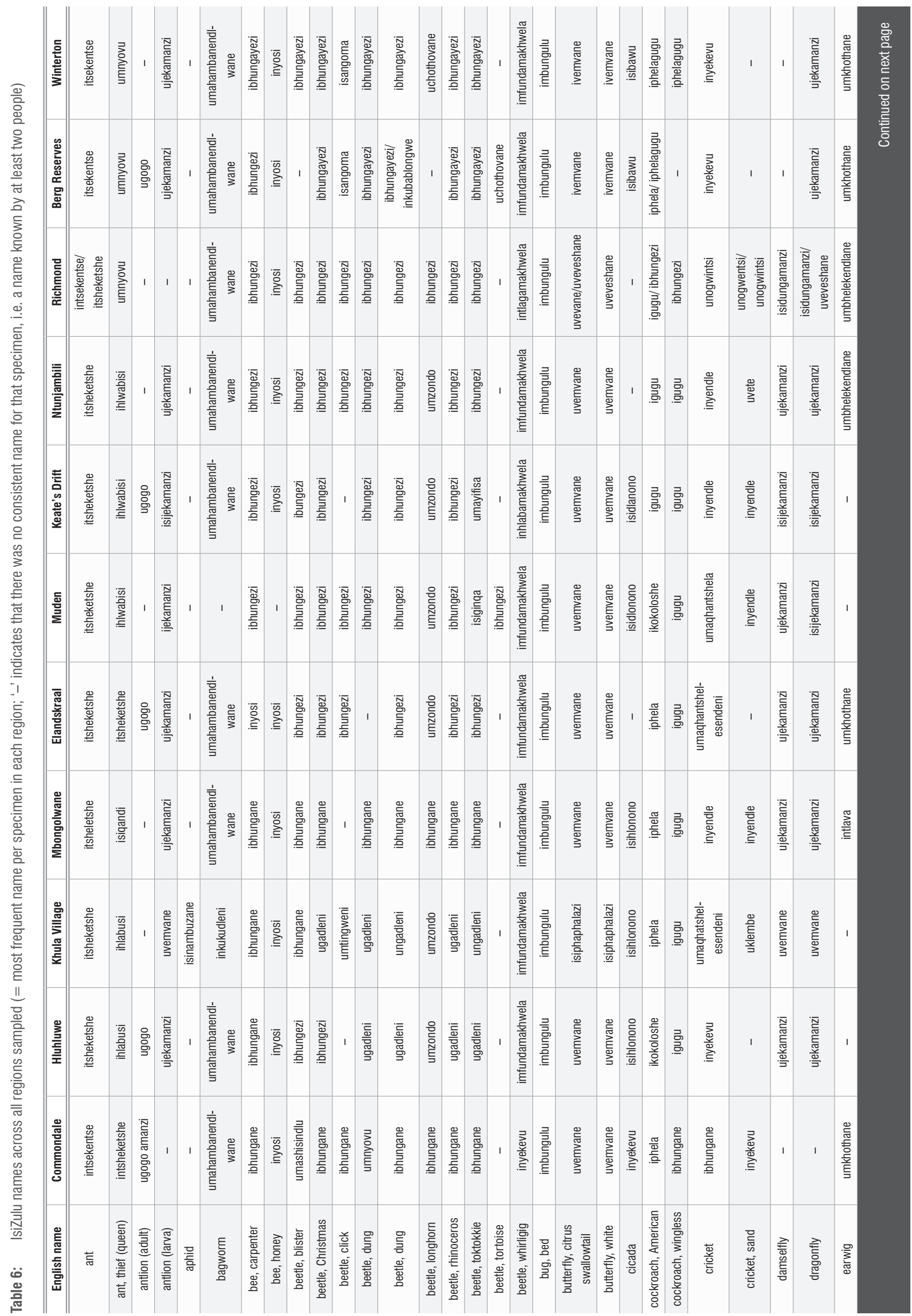




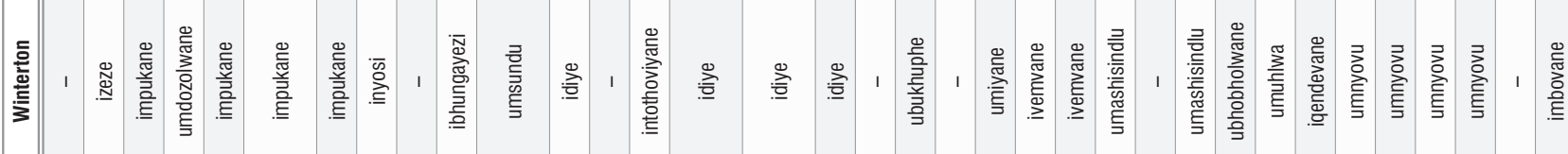

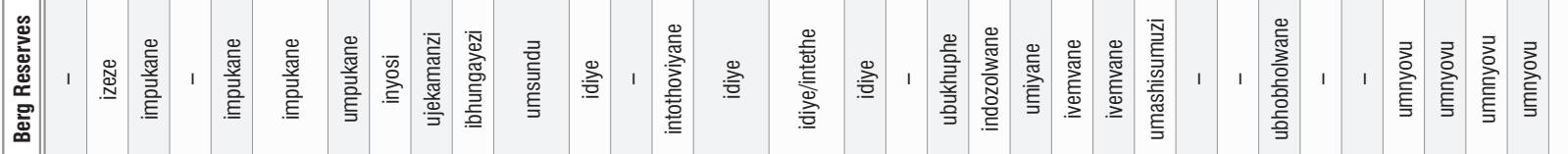

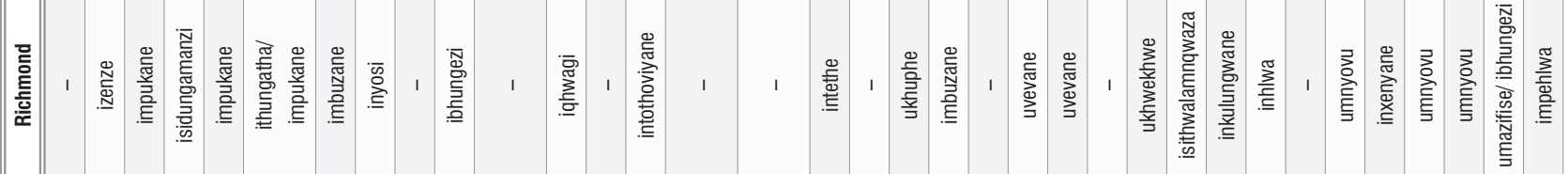

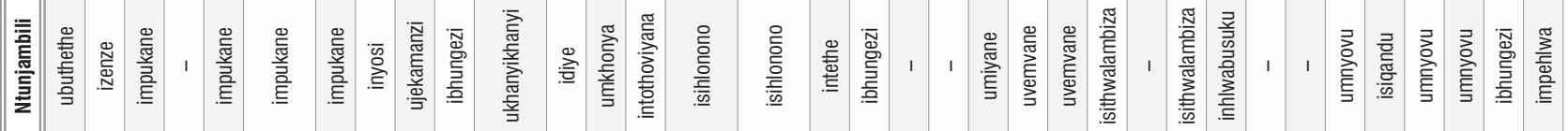

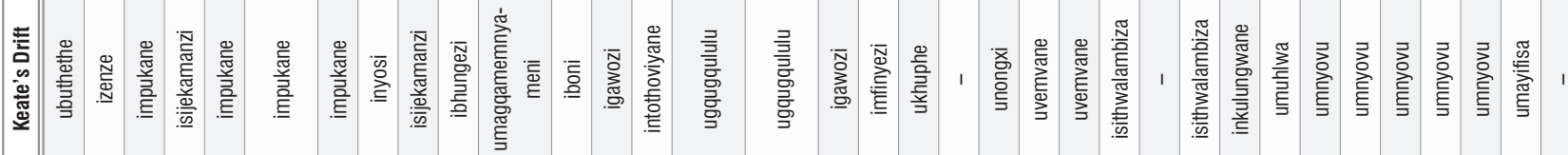

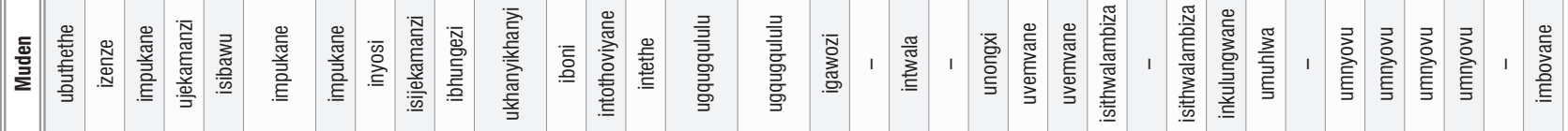

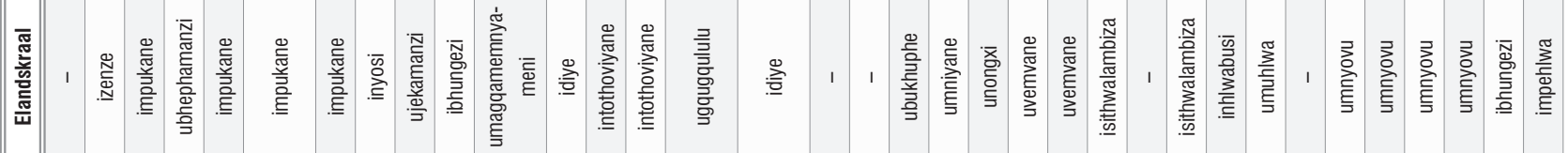

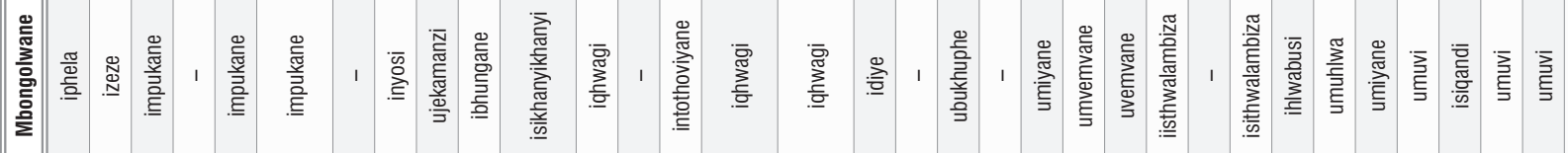

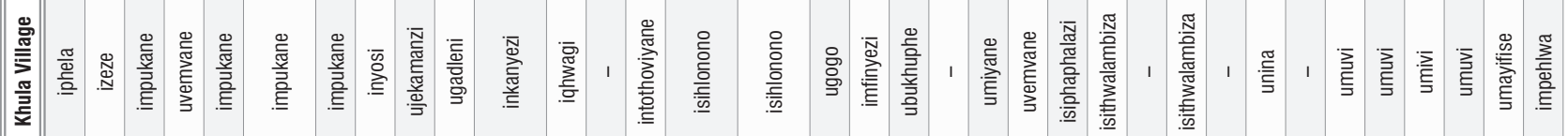

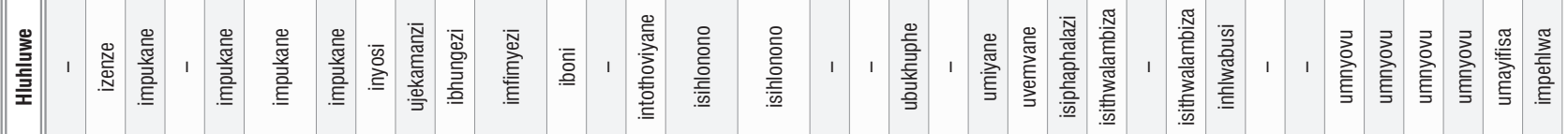

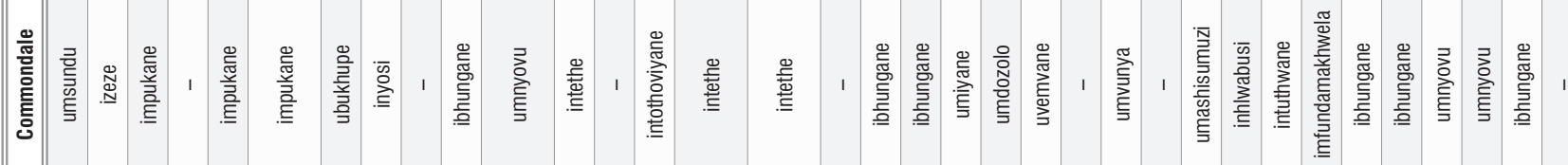

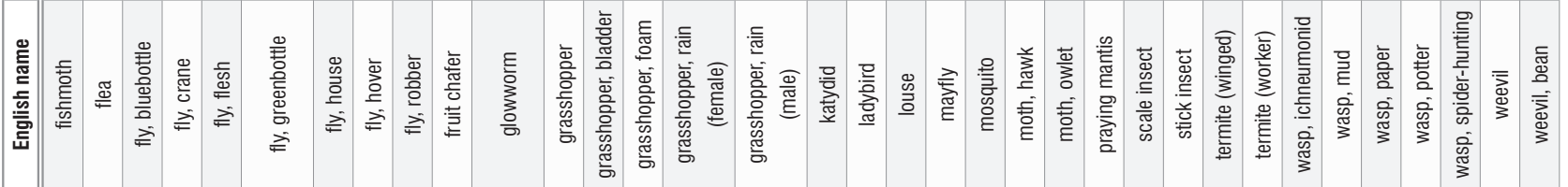




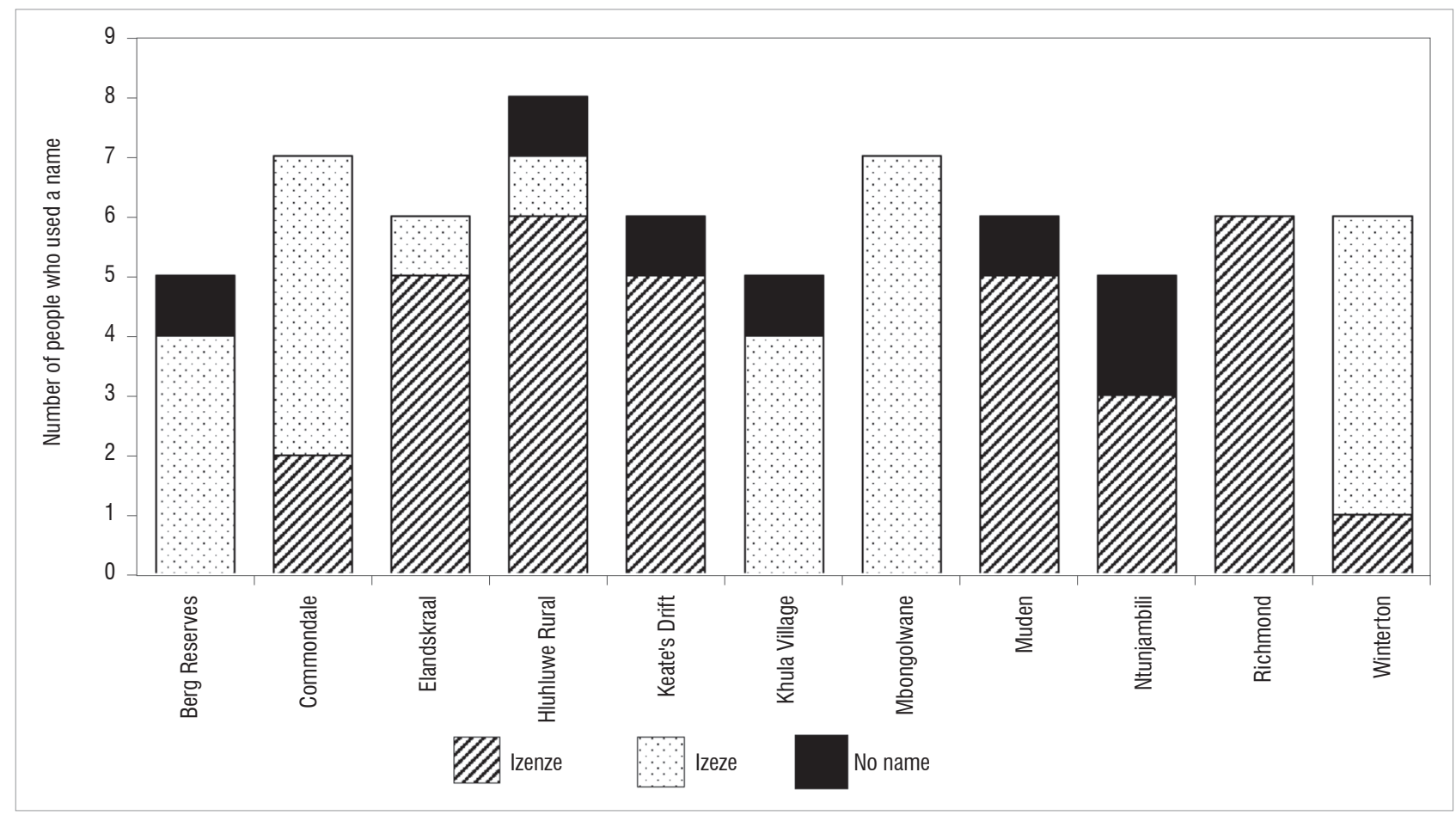

Figure 6: The isizulu name for fleas (Siphonaptera: Pulicidae) varies across regions. The term izenze is more common in the centre of the province (Elandskraal, Muden, Keate's Drift, Ntunjambili, Hluhluwe), and izeze is more common in the peripheral coastal (Mbongolwane, Khula Village) and mountain (Berg reserves, Winterton, Commondale) regions (cf. Figure 1).

Ideally, lexical variations that achieve a certain level of universal intelligibility cannot be overlooked when compiling a descriptive dictionary. Isihlonipho, the alternative term resorted to in a particular instance, poses an interesting challenge to defining an appropriate level of universality for this selection criterion because although names generated through it are frequently personal and apparently rife (e.g. Figure 3), they are also widely understood. Because the exhaustive description of isizulu might appear impracticable, Koopman ${ }^{39}$ suggested that one mentions the general phenomenon of high variation and catalogues only the key variants of each name. Presumably lexicons aimed at standardisation would ignore much of the dialectal, cultural, social and grammatical richness of languages like isizulu because of their distinctive agenda.

\section{Conclusion}

This list could be a valuable reference for professionals working on reciprocal technology transfer in the fields of applied entomology, environmental education, and agricultural, veterinary and medical extension work in communities in which isizulu is spoken predominantly. It also facilitates further studies of cultural entomology and research into isizulu folklore relating to insects. This is of interest as insects play a major role in human society: as pests and transmitters of diseases, and as a useful and beneficent presence that is intricately linked to human livelihood. ${ }^{48}$

This study will hopefully prove fruitful as a research model even though it was not focused on technical linguistic issues. It highlights the need for interdisciplinary teamwork in the field of indigenous knowledge research and the challenges facing the standardisation of South African languages.

\section{Acknowledgements}

Foremost, we thank the 67 respondents who sat patiently with the field researchers and generously shared their knowledge of insects. We also thank Milton Ngeju (Department of Zoology and Entomology, Rhodes University) for letting us use the departmental collection of preserved insect specimens; Matthias Bodenstein, Rob Crausaz, Sigrid Dedekind, Ncane Ndulini, Vic Schütte, Anittah Sithole, Reneé Stockil and Roland Vorwerk for assisting us in making contact with local Zulu communities;
Kevin and Stella Cockburn for transport and accommodation in the field, and encouragement; Stella Cockburn for assistance in compiling the list of isizulu names and for proofreading; Adrian Koopman (University of KwaZulu-Natal) for access to his unpublished work on isizulu animal and plant names; Helen Henninger (INRIA, Antibes, France) for pointing out the custom of resorting to isiHlonipo; Bernadette Hubbart for reference material; and Rhodes University for funding.

\section{Authors' contributions}

J.J.C. (student) led and conducted the majority of the research, including the design, data collection through interviews, analysis and write-up. B.K.-S. provided input into the writing process, in particular with the history of the isizulu language development. He also ensured language accuracy of the lists of names collected. M.V. supervised the student and provided conceptual input into the research design and process, and assisted with the analysis and write-up.

\section{References}

1. Sillitoe P. The development of indigenous knowledge: $A$ new applied anthropology. Curr Anthropol. 1998;39:223-252. http://dx.doi.org/10.1086/ 204722

2. Björnsen Gurung A. Insects - A mistake in God's creation? Tharu farmers' perception and knowledge of insects: A case study of Gobardiha Village Development Committee, Dang-Deukhuri, Nepal. Agric Human Values. 2003;20:337-370. http://dx.doi.org/10.1023/B:AHUM. $0000005149.30242 .7 f$

3. Sillitoe P, Dixon P, Barr J. Indigenous knowledge inquiries: A methodologies manual for development. Rugby: ITDG Publishing; 2005.

4. Beaudreau A, Levin P, Norman K. Using folk taxonomies to understand stakeholder perceptions for species conservation. Conserv Lett. 2011;4:451463. http://dx.doi.org/10.1111/j.1755-263X.2011.00199.x

5. Tibuhwa DD. Folk taxonomy and use of mushrooms in communities around Ngorongoro and Serengeti National Park, Tanzania. J Ethnobiol Ethnomed. 2012;8:36. http://dx.doi.org/10.1186/1746-4269-8-36 
6. Abate T, Van Huis A, Ampofo JKO. Pest management strategies in traditional agriculture: An African perspective. Annu Rev Entomol. 2000;45:631-659. http://dx.doi.org/10.1146/annurev.ento.45.1.631

7. Penel J-D. Epistemological reflections on Hausa zoological names. In: Hountondji P, editor. Endogenous knowledge: Research trails. Dakar: CODESRIA; 1997. p. 169-188

8. Guthrie M. The classification of the Bantu languages. London: Oxford University Press for the International African Institute; 1948.

9. Guthrie M. Comparative Bantu, 2: Bantu prehistory, inventory and indexes. London: Gregg International; 1971.

10. Nurse D, Philippson G. Towards a historical classification of the Bantu languages. In: Nurse D, Philippson G, editors. The Bantu languages. London, New York: Routledge; 2003. p. 164-181.

11. Maho JF. NUGL online: The online version of the New Updated Guthrie List, a referential classification of the Bantu languages [document on the Internet]. c2009 [cited 2013 July 31]. Available from: http://goto.glocalnet.net/ mahopapers/nuglonline.pdf

12. Silinyana A. Molo gqirha - Hello doctor. East London: Nation Building Books; 2000.

13. Dijté $P$. The sociolinguistics of development in Africa. Clevedon: Multilingual Matters; 2008.

14. Mufwene S. Language evolution. Contact, competition and change. London, New York: Continuum; 2008

15. Statistics South Africa. Census 2011: Census in brief [homepage on the Internet]. c2012 [cited2013 July 07]. Available from: http://statssa.gov.za

16. Lewis MP, Simons GF. Assessing endangerment: Expanding Fishman's GIDS. Rev Roum Linguist. 2010;55:103-120.

17. Feely JM. IsiXhosa names of South African land mammals. Afr Zool. 2009;44:141-150. http://dx.doi.org/10.3377/004.044.0202

18. International Commission on Zoological Nomenclature. International code of zoological nomenclature. 4th ed. London: International Trust for Zoological Nomenclature; 1999.

19. Platt J, Weber H, Ho M. The new Englishes. London: Routledge \& Kegan Paul; 1984.

20. Scholtz C, Holm E. Insects of southern Africa. Durban: Butterworths; 1985.

21. Mkize N, Villet MH, Robertson MP. IsiXhosa insect names from the Eastern Cape, South Africa. Afr Entomol. 2003;11:261-276.

22. Uys $C$, McLarty S. My first book of southern African creepy-crawlies. Cape Town: Random House Struik; 2010.

23. White $P$, Woods R. The geographical impact of migration. New York: Longman; 1980.

24. Blair F. Survey on a shoestring: A manual for small-scale language surveys. Dallas: Summer Institute of Linguistics and University of Texas at Arlington; 1990.

25. Babbie E. The practice of social research. Belmont: Wadsworth; 2010.

26. McColl E, Jacoby A, Thomas L, Soutter J, Bamford C, Steen N, et al. Design and use of questionnaires: A review of best practice applicable to surveys of health service staff and patients. Health Technol Assess Rep. 2001;5(31):1-252.
27. Partington G. Qualitative research interviews: Identifying problems in technique. Issues Edu Res. 2001;11:32-44.

28. Diamond J, Bishop KD. Ethno-ornithology of the Ketengban people, Indonesian New Guinea. In: Medin DL, Atran S, editors. Folkbiology. Cambridge, MA Massachusetts Institute of Technology; 1999.

29. Lietz P. Research into questionnaire design. Int J Market Res. 2010;52:249272. http://dx.doi.org/10.2501/S147078530920120X

30. Soberón MJ, Llorente BJ. The use of species accumulation functions for the prediction of species richness. Conserv Biol. 1993;7:480-488. http://dx.doi. org/10.1046/j.1523-1739.1993.07030480.x

31. Colwell RK, Chang X, Chang J. Interpolating, extrapolating, and comparing incidence-based species accumulation curves. Ecology. 2004;98:27172727. http://dx.doi.org/10.1890/03-0557

32. Fagen RM, Goldman RN. Behavioural catalogue analysis methods. Anim Behav. 1977;25:261-274. http://dx.doi.org/10.1016/0003-3472(77)90001-X

33. Doke CM, Malcolm DM, Sikakana JMA, Vilakazi BW. English-Zulu ZuluEnglish dictionary. Johannesburg: Witwatersrand University Press; 2005.

34. Cockburn JJ, Witthöft J, Coetzee HC, Van den Berg J, Conlong DE, Lesage S. Small-scale sugarcane farmers' knowledge of sugarcane insect pests. Proceedings of the 86th Congress of the South African Sugarcane Technologists' Association; 2013 August 6-8; Durban, South Africa. Available from: http://www.sasta.co.za/publications/congress-proceedings

35. Bryant AT. Bantu origins. Cape Town: Struik; 1963.

36. Werner A. The custom of 'isiHlonipo' in its influence on language. J Roy Afr Soc. 1905;4:346-356.

37. Rudwick S, Shange M. Hlonipha and the rural Zulu woman. Agenda. 2009;23:66-75

38. Fandrych I. Between tradition and the requirements of modern life: Hlonipha in southern Bantu societies, with special reference to Lesotho. J Lang Cult. 2012;3:67-73.

39. Koopman A. Zulu plant name variation. Unpublished essay. Pietermaritzburg: School of isiZulu Studies, University of KwaZulu-Natal; 2006.

40. Koopman A. Zulu names. Pietermaritzburg: University of Natal Press; 2002.

41. Brown $\mathrm{CH}$. The growth of ethnobiological nomenclature. Curr Anthropol. 1986;27:1-19. http://dx.doi.org/10.1086/203375

42. Bailenson J, Shum M, Atran S, Medin D, Coley J. A bird's eye view: Biological categorization and reasoning within and across cultures. Cognition. 2002;84:1-53. http://dx.doi.org/10.1016/S0010-0277(02)00011-2

43. Vilakazi A. Zulu transformations. A study of the dynamics of social change. Pietermaritzburg: University of Natal Press; 1965.

44. Mbanjwa T. Black consciousness. In: Mbanjwa T, editor. Black review 1974/75. Durban: Black Community Programmes; 1975. p. 131-139.

45. Alexander N. Thoughts on the new South Africa. Johannesburg: Jacana Media; 2013.

46. Kaschula RH, Anthonissen C. Communicating across cultures in South Africa. Johannesburg: Witwatersrand University Press; 2001.

47. Fontenelle T. Lexicography. In: Simpson J, editor. The Routledge handbook of applied linguistics. Abingdon, New York: Routledge; 2011. p. 53-66.

48. Hogue CL. Cultural entomology. Annu Rev Entomol. 1987;32:181-199. http://dx.doi.org/10.1146/annurev.en.32.010187.001145 